\title{
La denuncia de la represión clandestina durante la dictadura en Argentina: el caso de los sobrevivientes de Vanguardia Comunista $(1978-1983)^{*}$
}

\author{
The denounce of the clandestine repression during dictatorship in Argentina: \\ the case of Vanguardia Comunista survivors (1978-1983)
}

\author{
Rodrigo González Tizón ${ }^{* *}$
}

\begin{abstract}
Resumen: La última dictadura militar en Argentina (1976-1983) implementó como principal instrumento represivo el secuestro y posterior cautiverio ilegal de opositores políticos. Focalizando en caso de un grupo de sobrevivientes del partido Vanguardia Comunista liberados del centro clandestino de detención "El Vesubio", ubicado en la Provincia de Buenos Aires, este artículo se propone examinar el rol de esta porción de las víctimas de la represión -junto a familiares de los desaparecidos y a las estructuras partidarias- en la denuncia de la violencia estatal previo al retorno de la democracia.
\end{abstract}

Palabras clave: dictadura, Argentina, Vanguardia Comunista, derechos humanos, sobrevivientes

Resumen: The last military dictatorship in Argentina (1976-1983) implemented as its most important repressive tool the kidnaping and subsequent captivity of political opponents. Focusing on the case of a group of survivors belonging to Vanguardia Comunista party released from the clandestine detention center known as 'El Vesubio', located in the surroundings of Buenos Aires, this article aims to examine the rol played by this portion of the repression victims -together with relatives of the disappeared and the party structuresin the denounce of the state violence before de return of democracy.

Key words: dictatorship, Argentina, Vanguardia Comunista, human rights, survivors

Recibido: 7 febrero 2018

Aceptado: 28 marzo 2018

\footnotetext{
* Agradezco los comentarios realizados a versiones previas de este trabajo por María José Sarrabayrouse Oliveira, Pablo Scatizza, los miembros del "Núcleo de Política, Sociedad y Cultura en la historia reciente del Cono Sur" del IDAES y, especialmente, por parte de mis colegas del "Conventillo de Teodoro" Hernán Confino, Julián Delgado, Andrés Gattinoni y Leandro Lacquaniti. Ninguno de ellos es responsable de los errores y/u omisiones en artículo, que corren por cuenta exclusiva del autor.

** Argentino, Profesor de Historia (UBA). Actualmente doctorando del Instituto de Altos Estudios Sociales de la Universidad Nacional de San Martín (IDAES-UNSAM). Becario doctoral interno del Consejo Nacional de Investigaciones Científicas y Técnicas (CONICET) con sede en el Instituto de Investigaciones Gino Germani (IIGG). Dirección de correo electrónico: rgtizon@gmail.com
} 


\section{Introducción}

La madrugada del 30 de julio de 1978, Paulino Guarido, un maestro de veintidós años, fue liberado cerca de su casa del barrio de Lugano, en el límite sudoeste de la Capital Federal de la República Argentina, luego de permanecer secuestrado diez días en un sitio desconocido. El 2 de agosto se presentó espontáneamente ante la Justicia para declarar por su secuestro y el de su esposa, quien continuaba cautiva. En un contexto marcado por la represión de toda disidencia al régimen militar, el suyo era un acto fuera de lo común. $\mathrm{Su}$ iniciativa, sin embargo, encontró una respuesta no menos atípica de parte del juez a cargo del juzgado, el Dr. Carlos Oliveri. A diferencia de la mayoría de sus colegas, el magistrado se mostró dispuesto a oír lo que Guarido tenía para contarle. A partir de este encuentro cobró vida una de las más tempranas investigaciones judiciales por los crímenes de la última dictadura en Argentina: la causa n³5.040/78. La pesquisa desencadenada permitiría, luego de diversas idas y vueltas que amenazaron con el naufragio de la investigación, establecer que el lugar donde la pareja había estado secuestrada era el centro clandestino de detención (CCD) "El Vesubio"1.

El lugar de cautiverio funcionó desde los inicios de la dictadura, en marzo de 1976, hasta finales del año 1978, cuando fue demolido por orden de las Fuerzas Armadas. Poco tiempo antes de su desmantelamiento, los responsables de El Vesubio tomaron la decisión de liberar a una parte de las personas allí cautivas. Entre los hombres y mujeres liberados se encontraba un importante contingente de militantes del partido Vanguardia Comunista (VC). Parte de la denominada "Nueva Izquierda" argentina, la organización surgió el 5 de abril de 1965 como producto de una escisión del Partido Socialista Argentino de Vanguardia (PSAV), desprendimiento del Partido Socialista Argentino (PSA). Se trató de una fuerza política de orientación maoísta con una mirada crítica de la estrategia de la lucha $\operatorname{armada}^{2}$. Su primer Secretario General fue Elías "el Turco" Semán, reemplazado en el cargo a partir de 1971 por Roberto "el Cabezón" Cristina. Entre julio y agosto de 1978, sesenta militantes de esa fuerza política fueron secuestrados en diversos puntos de la Capital Federal y en la Provincia de Buenos Aires, en lo que constituyó el golpe más fuerte recibido por la organización a manos de la dictadura. De dicho total, cuarenta hombres y mujeres fueron liberados por decisión de sus captores, mientras que el resto aún hoy continúa desaparecido.

Con la causa como telón de fondo y una parte de los sobrevivientes de VC como columna vertebral, durante la dictadura se desarrollarían iniciativas tendientes a echar luz

\footnotetext{
${ }^{1}$ El Vesubio fue uno de los mayores CCD en funcionamiento durante la última dictadura argentina bajo la órbita del Primer Cuerpo de Ejército. El lugar estaba ubicado en La Matanza, partido de la zona Oeste del Gran Buenos Aires, a la vera de la autopista Ricchieri, camino al aeropuerto internacional de Ezeiza. Junto al Ejército, participaron de la represión en El Vesubio personal de la Policía de la Provincia de Buenos Aires y del Servicio Penitenciario Federal. Al día de la fecha, la investigación judicial por los crímenes cometidos en ese CCD acreditó el cautiverio trescientas sesenta personas en dicho lugar. Dado el carácter clandestino de la represión, la cifra es provisoria.

2 Brenda Rupar, A emergência do Maoismo na Argentina: uma aproximaçao através de Vanguardia Comunista $e$ o Partido Comunista Revolucionario, Tesis de maestría en Historia, Universidad de Fluminense, 2016.
} 
sobre la maquinaria represiva de El Vesubio. Para que éstas tuvieran éxito, fue fundamental la articulación de los sobrevivientes con las estructuras partidarias -más bien, lo que quedaba de ellas luego del golpe asestado a la organización por parte de la dictadura-, con los familiares de los compañeros de militancia desaparecidos y con un conjunto de organismos de derechos humanos del ámbito local e internacional. El resultado final de este esfuerzo colectivo de denuncia sería, pocos días antes del retorno de la democracia, la identificación del predio donde había funcionado el CCD.

Este artículo explora las prácticas de denuncia desarrolladas por los sobrevivientes de VC secuestrados en El Vesubio en una etapa previa al retorno de la democracia, período poco explorado en la trayectoria de dicho segmento de las víctimas de la represión ${ }^{3}$. Entonces, no se había producido todavía la emergencia pública de los sobrevivientes, que tendría lugar en el contexto del informe de la Comisión Nacional sobre la Desaparición de las Personas (CONADEP) y del Juicio a las Juntas -en 1984 y 1985, respectivamente- y como consecuencia de la importancia de sus testimonios para la producción de evidencia judicial sobre la represión. La centralidad de esos acontecimientos claves en la refundación del Estado de Derecho y en la consolidación de un primer régimen de memoria sobre el pasado dictatorial en Argentina, paradójicamente, redundó en cierto oscurecimiento del accionar de los sobrevivientes durante los años de dictadura. Al mismo tiempo, dicha coyuntura fue central para la cristalización una imagen de este segmento de las víctimas de represión ligada a la figura del testigo ${ }^{4}$. Este artículo se sitúa a contracorriente de este modo de concebir a los sobrevivientes y su participación en el movimiento de la denuncia humanitaria proponiendo, en su lugar, una aproximación a su figura que pone en primer plano su condición de actores políticos destacados en el terreno de la lucha antidictatorial.

El examen de las prácticas de denuncia desarrolladas por los sobrevivientes de VC cautivos en El Vesubio pone en cuestión algunos de los supuestos instalados sobre el papel de este segmento de las víctimas de la represión en la etapa previa al retorno de la democracia. En primer lugar, permite ponderar el rol de los sobrevivientes en el movimiento de oposición al régimen militar, muchas veces considerado como secundario ${ }^{5}$.

\footnotetext{
3 Entre las pocas excepciones a esta afirmación se cuentan Mariana Tello, "Yo acuso: un análisis antropológico sobre lo jurídico en los primeros testimonios sobre 'La Perla"', en Clepsidra, Revista interdisciplinaria de estudios sobre memoria n4, 2015, y Rodrigo González Tizón, “'Cada voz que se alce puede salvar una vida en Argentina'. La producción testimonial de los sobrevivientes de los Centros Clandestinos de Detención en el marco de la Comisión Argentina por los Derechos Humanos (1979-1983), en Papeles de Trabajo, 10(17), 2016.

${ }^{4}$ Esta invisibilización de la trayectoria de denuncia de los sobrevivientes durante la dictadura y su asociación temprana con la figura del testigo repercutieron directamente en el curso de la investigación académica sobre su figura. A modo de ejemplo, véase Christian Dürr, Memorias incómodas. El dispositivo de la desaparición y el testimonio de los sobrevivientes de los Centros Clandestinos de Detención, Tortura y Exterminio, Temperley, Tren en Movimiento, 2017; Claudia Feld y Luciana Messina, "En torno a la palabra testimonial de los sobrevivientes: testigos legitimados y denegados de los centros clandestinos de detención en Argentina", en Tramas, n41, 2014; Ana Forcinito, Los umbrales del testimonio. Entre las narraciones de los sobrevivientes y las señas de la posdictadura, Madrid, Iberoamericana, 2012; entre otros.

${ }^{5}$ Existen numerosos trabajos que tematizan el rol cumplido en la oposición al régimen militar por exiliados (Marina Franco, El exilio. Argentinos en Francia durante la dictadura, Buenos Aires, Siglo XXI, 2008; Silvina Jensen, Los exiliados. La lucha por los derechos humanos durante la dictadura, Buenos Aires, Sudamericana, 2010.; Pablo Yankelevich, Ráfagas de un exilio. Argentinos en México: 1974-1983, Buenos
} 
Lejos de asumir una actitud pasiva o limitada a la producción de relatos sobre el cautiverio clandestino, los sobrevivientes de VC desplegaron durante los años de dictadura, en el marco de un colectivo de denuncia más amplio, diversas iniciativas que incluyeron, entre otras, la publicación de solicitadas en la prensa local, la presentación de escritos judiciales y la difusión de los crímenes de la Junta Militar ante diversos interlocutores internacionales. De este modo fue posible acumular, en una época temprana, un conjunto de saberes sobre la represión en El Vesubio que resultarían fundamentales en los inicios de la etapa democrática. A pesar de las particularidades de la trayectoria de los sobrevivientes de VC, el abordaje de su caso ofrece claves de lectura para pensar recorrido general de este segmento de las víctimas de la represión en tiempos de dictadura.

De manera subsidiaria, el análisis de la experiencia del conjunto de sobrevivientes seleccionado aporta elementos que complejizan el cuadro general del proceso histórico del régimen militar. En primer lugar, problematiza el rol del Poder Judicial, tradicionalmente reducido a una complicidad total con los secuestros, las muertes y las desapariciones. Contra esta visión monolítica, el caso elegido saca a relucir una cara menos explorada de la justicia, en la que los tribunales no funcionan simplemente como un instrumento automático de legitimación de la represión, sino como un complejo entramado de actores en el que también se abrieron resquicios -aunque fueran mínimos- para la denuncia de las violaciones a los derechos humanos en el país.

La reconstrucción de las prácticas de denuncia de los sobrevivientes de VC en la etapa seleccionada ofrece, a su vez, una ventana para observar la densidad del aparato represivo montado durante la dictadura. En las sucesivas intervenciones de los sobrevivientes, el CCD -consagrado en la transición democrática como el epicentro de la represión dictatorial- convive con todo un conjunto de dependencias policiales, militares y penitenciarias de carácter legal, por las cuales transitaron los secuestrados en su camino hacia la liberación. Esta evidencia de los contactos fluidos entre El Vesubio y las dependencias legales obligan a pensar la represión como un fenómeno de naturaleza bifronte, compuesto por una faceta legal y otra clandestina ${ }^{6}$.

Aires: Fondo de Cultura Económica, 2010), organismos de derechos humanos locales (Luciano Alonso, "La definición de las ofensas en el movimiento por los derechos humanos en Argentina y la calificación de 'Genocidio"', en Contenciosa, Buenos Aires, Año I, N 1, 2013; Elizabeth Jelin, "La política de la memoria: el movimiento de derechos humanos y la construcción democrática en la Argentina", en Juicio, castigo y memorias. Derechos humanos y justicia en la política argentina, Buenos Aires, Nueva Visión, 1995; Nadia Tahir, Les asociations des victimes de la dictature: politiques de droits de l'homme et devoir de mémoire en Argentine (1976-2007), Tesis de doctorado, Université Paris-Sorbonne, 2011) y diversas organizaciones políticas y sindicales argentinas (Álvaro Abós, Las organizaciones sindicales y el poder militar (1976-1983), Buenos Aires: CEAL, 1984; Hernán Confino, "Volver sin haberse ido: el caso de las 'Tropas de Agitación Sur' durante la Contraofensiva Estratégica Montonera de 1979', en Revista Universitaria de Historia Militar (en prensa); Richard Gillespie, Soldados de Perón. Historia crítica sobre los Montoneros, Buenos Aires: Sudamericana, 2008). Esta situación se contrapone al importante vacío historiográfico en torno al papel desempeñado por los sobrevivientes de los CCD dentro del movimiento de la denuncia humanitaria durante los años de dictadura.

${ }^{6}$ Para un examen minucioso de la naturaleza estatal y paraestatal de la represión dictatorial, véase Gabriela Águila et al, Represión estatal y violencia paraestatal en la historia reciente argentina. Nuevos abordajes a 40 años del golpe de Estado, Buenos Aires: FaHCE-UNLP, 2016. 


\section{Primeros indicios de la represión: la causa n³5.040/78}

\section{Un encuentro extraordinario}

María Isabel Ávalos de Guarido se presentó el 25 de julio de 1978 en la comisaría 48va del barrio porteño de Villa Lugano ${ }^{7}$ para denunciar el secuestro de su hijo y su nuera. De acuerdo con la versión mecanografiada de su relato, "personas de civil, armadas (...) ingresaron a la vivienda, procediendo a detener a su hijo, Paulino Alberto Guarido (...), casado, estudiante y maestro, allí domiciliado, y a su esposa, Mónica Haydeé Piñeiro (...) maestra (...), retirándose de la finca, dichas personas con su hijo y su nuera" ${ }^{\text {. Desde }}$ entonces, la mujer no había tenido noticias de la pareja, a pesar de los numerosos intentos realizados por dar con su paradero.

En su investigación sobre el Poder Judicial durante la dictadura, Sofía Lanzilotta y Lucía Castro Feijóo reconstruyeron el derrotero "normal" de los innumerables habeas corpus presentados por los familiares de los desaparecidos:

El trámite de los expedientes de hábeas corpus consistía (...) en que los jueces enviaran despachos (notas de requerimientos oficiales) a los organismos de Seguridad y militares consultando si se encontraba detenida la persona buscada; en la gran mayoría de los casos la respuesta sistemática era que no se registraban antecedentes de detención de las personas referidas. Con esta contestación se pasaba vista al fiscal y a las partes, tras lo cual la sentencia dictada era que esa persona no se hallaba detenida, que el recurso no era procedente y, por lo tanto, se lo rechazaba ${ }^{9}$.

Detrás del procedimiento burocrático que conducía al rechazo sistemático de los habeas corpus se escondía la connivencia de los representantes del orden legal con la maquinaria represiva clandestina: "lo cotidiano" en los tribunales de aquellos años consistía en que los funcionarios judiciales hicieran caso omiso de las evidencias de los crímenes dictatoriales ${ }^{10}$. Esto conducía a que la abrumadora mayoría de las veces los expedientes iniciados por privaciones ilegítimas de la libertad quedaran olvidados en algún recóndito cajón de un juzgado.

En el caso de los sobrevivientes de El Vesubio, el quiebre de lo cotidiano judicial vino de la mano de dos acontecimientos atípicos para el contexto de la época: la presentación del propio Guarido ante el Juzgado Nacional de Instrucción en lo Criminal No3 (JI3) con la intención de contar los pormenores de su secuestro y del de su esposa, y la disposición del juez Oliveri de escuchar y dar crédito a su palabra ${ }^{11}$. Fue este encuentro

\footnotetext{
${ }^{7}$ El barrio de Villa Lugano se ubica en el límite sudoeste de la Ciudad Autónoma de Buenos Aires, separado del partido de La Matanza por la avenida General Paz.

8 Juzgado Nacional de Instrucción en lo Criminal n³, causa n ${ }^{\circ}$ 35.040/ 78, “Ávalos de Guarido, Isabel s/denuncia", fs. 1-2.

9 Lucía Castro Feijóo y Sofía Lanzilotta, Justicia y Dictadura. Operadores del plan cívico-militar en Argentina, Buenos Aires, Ediciones del CCC, 2014.

${ }^{10}$ Sarrabayrouse Oliveira, op. cit, p.22.

${ }^{11}$ El Juzgado Nacional de Instrucción en lo Criminal №3 tenía jurisdicción sobre la Ciudad Autónoma de Buenos Aires. Su titular al momento de los hechos analizados era el Dr. Carlos Oliveri y su secretario, el Dr.
} 
extraordinario el que convirtió el impulso de una madre ante la desaparición de su hijo cuyo destino "normal" lo constituía la indiferencia de los letrados- en el origen de una investigación judicial que atravesaría toda la dictadura y llegaría hasta el período democrático.

En su trabajo sobre la morgue judicial, Sarrabayrousse Oliveira se referiere al Dr. Oliveri. Según sus entrevistados, miembros del Poder Judicial e integrantes de organismos de derechos humanos de la época, el magistrado se incluía dentro del reducido grupo de "jueces que investigaban"12. De formación liberal, Oliveri defendía la democracia y el sistema republicano, y con ellos las obligaciones que comportaba la investidura de juez. Estos principios se vieron reflejados, incluso, en un contexto represivo como el de la última dictadura, tal como lo recuerda una abogada del CELS que ofició de representante legal de víctimas de la represión durante esa época:

Lo que hacía por ejemplo Oliveri, era tratar de investigar todo lo posible y después sobreseía dejando a salvo que tenía que sobreseer, y que en algún momento en otra etapa se podría reabrir la causa dejando a salvo que no podía hacer más nada, digamos. No sobreseía porque no hubiera sucedido el hecho (...) Pero había ya elementos (...) Que eso era lo bueno, que pudiera juntar todos los elementos para cuando cambiara la mano. Porque el juez tenía un límite: realmente no podías entrar a un campo clandestino de detención. Y el que más hizo en estas causas es Oliveri ${ }^{13}$.

Mediante el recurso al "sobreseimiento provisional" -instrumento que aplicaría asiduamente en el curso de la investigación judicial por los secuestros en El VesubioOliveri garantizaba que los expedientes por denuncias permanecieran abiertos, recabando toda la información que el clima de persecución permitía. Este modo de proceder, aún con los límites evidentes que entrañaba, lo convertía en un "distinto" dentro del universo judicial de la época: a los ojos de sus contemporáneos, Oliveri "no era un juez más"14.

En este contexto fue que, en la mañana del 2 de agosto de 1978, Guarido ofreció su primera declaración ante el JI3. Así recuerda, a casi cuatro décadas de los hechos, sus sensaciones a la hora de testimoniar ante los funcionarios judiciales de turno:

había cierta situación que yo notaba de incomodidad. También supongo que era muy raro para los secretarios del juzgado que de pronto apareciera uno de los que estaba denunciado como secuestrado, debía ser muy raro para ellos también quién era yo, como había aparecido, qué tenía para declarar. (...) Los secretarios ponían parte de los que yo decía, imagino que ponían lo que podían -o lo que querían-, no ponían todo ${ }^{15}$.

La desconfianza fue, en este primer encuentro, una constante. En esa primera exposición breve, de dos páginas mecanografiadas, Guarido narró su secuestro, cautiverio y posterior liberación, dejando constancia de la permanencia de su esposa en el lugar de

Luis Fernando Niño.

${ }^{12}$ Sarrabayrouse Oliveira, op. cit, p.68.

${ }^{13}$ Sarrabayrouse Oliveira, op. cit. Pp.69-70.

${ }^{14}$ Sarrabayrouse Oliveira, op. cit, p.68.

${ }^{15}$ Paulino Guarido, entrevista con el autor, Ciudad Autónoma de Buenos Aires, 24 de septiembre de 2015. 
detención. El relato era magro, posiblemente producto del temor de ambas partes a decir o saber demasiado: no aparecían en la declaración referencias a las identidades de los otros detenidos, y eran lacónicas las menciones a los captores. Se esbozaban, sí, unas primeras coordenadas geográficas del lugar de cautiverio, aunque insuficientes para determinar la ubicación exacta del mismo: sólo se indicaba que "se notaba que estaba sobre una ruta"16.

Ante la pregunta por su actividad política, Guarido silenció toda información respecto a su militancia y la de su pareja -vinculada a VC-, afirmando que, "lo mismo que su esposa", "no tuvo participación en ninguna organización o movimiento"17. LA evasiva era coherente con el contexto además de la represión clandestina y de la concepción particularmente presente en el imaginario de la época- que asociaba la militancia con la subversión, existía toda una legislación que censuraba la actividad política, cuyo pilar fundamental era la ley n⿳20.840/ 74, conocida también como de "Seguridad Nacional y actividades subversivas ${ }^{18}$.

La actitud de Guarido reflejaba, además, la ambivalencia que rodeaba al Poder Judicial en tiempos de dictadura. Los tribunales, como se mencionó anteriormente, garantizaban una cobertura legal para la maquinaria represiva clandestina y, en este sentido, eran percibidos por muchas de las víctimas como un brazo más del régimen militar. Sin embargo, los estrados judiciales mantenían al mismo tiempo viva parte de esa aura que los asociaba con el acceso a la verdad y la justicia. Percepción que iba en consonancia con la imagen que la dictadura pretendía difundir sobre la vigencia del orden jurídico, y que se sustentaba en la ingente batería legal sancionada durante los años anteriores al golpe y en los primeros de la dictadura para llevar adelante la mentada lucha contra la subversión ${ }^{19}$. Aunque resuelta por lo general a favor de la faz represiva, la tensión entre esas dos dimensiones de la Justicia atravesó el funcionamiento de los tribunales durante la dictadura, poniendo de relieve la capacidad de agencia de ciertos actores individuales de la "familia judicial" 20 .

Pero, por sobre todas las cosas, y más allá de cualquier intención de la Junta Militar por construir una ficción de "normalidad" en torno al funcionamiento del Poder Judicial bajo su gobierno, los tribunales permitían dejar un registro de los hechos ocurridos. Esta circunstancia habilitaba, como pronto lo descubrirían los miembros de diversos organismos de derechos humanos locales, la posibilidad de hacer un uso estratégico de esa justicia que, a priori, se mostraba funcional al encubrimiento de los crímenes de la represión. Como consecuencia, las presentaciones judiciales se convertirían en una instancia casi ineludible

\footnotetext{
${ }^{16}$ Juzgado Nacional de Instrucción en lo Criminal n³, op. cit., fs.9/ vta.

${ }^{17}$ Ididem.

${ }^{18}$ La ley $n^{\circ}$ 20.840/ 74 fue sancionada en septiembre de 1974 en un tiempo récord de 48 horas. Pilar de una legislación represiva más amplia, en ella se sancionaba un amplio abanico de prácticas que involucraban desde la militancia en organizaciones políticas hasta la mera simpatía con las mismas, bajo la excusa de atentar contra el "Orden Institucional".

19 Véase Débora D'Antonio, Transformaciones y experiencias carcelarias. Prisión política y sistema penitenciario en la Argentina entre 1974 y 1983, Tesis de Doctorado en Historia, Buenos Aires, Facultad de Filosofía y Letras, UBA, 2010; Marina Franco, Un enemigo para la Nación. Orden interno, violencia y subversión, 1973-1976, Buenos Aires, Fondo de Cultura Económica, 2012.

${ }^{20}$ Sarrabayrouse Oliveira, op. cit.
} 
en el derrotero de denuncia de las desapariciones ${ }^{21}$.

Terminada la declaración testimonial, Oliveri remitió un oficio a la Policía Federal "recomendando (...) la individualización y captura del autor o autores" del secuestro de Guarido y su esposa, sin que el mismo encontrara eco. Ante esta situación, y "hasta tanto dicha diligencia [la identificación y detención de los secuestradores] no se haga efectiva", el magistrado resolvía en su dictamen del 10 de agosto el sobreseimiento provisional de la causa, que no registraba ningún imputado ${ }^{22}$. Si no cerradas, las actuaciones ingresaban en un letargo indefinido a la espera de nuevas pistas que permitieran retomar la senda investigativa.

\section{Los sobrevivientes hablan}

A fines de 1978, entre el 29 de noviembre y el día 6 del mes siguiente, nuevas declaraciones de personas que presuntamente habían estado secuestradas en el mismo lugar que Guarido -entre ellas, su esposa- reactivaron la causa a cargo del juez Oliveri. Esta vez, los relatos provenían de un grupo de detenidas en la Unidad Penitenciaría $\mathrm{n}^{\mathbf{0}} 2$ de Villa Devoto, ubicada en el barrio homónimo de la Capital Federal. Todas estaban a la espera de que se les efectuara el correspondiente Consejo de Guerra bajo la acusación de violar la normativa que penaba el supuesto accionar subversivo en el país. Las declaraciones habían sido efectuadas, sin embargo, ante un juez civil, el Dr. Oscar Mario Ocampos, en el marco de la instrucción de la causa $\mathrm{n}^{\circ} 12.912 / 78$, en la que se investigaba el secuestro de un

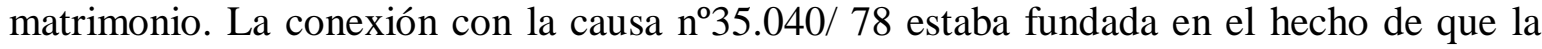
mujer de dicho matrimonio había sido legalizada junto a la esposa de Guarido.

El expediente con las declaraciones de las tres mujeres llegó a manos del Dr. Oliveri el 21 de diciembre, es decir, algunos días después de efectuados los testimonios. La primera de las declaraciones era la de Mónica Piñeiro. Vinculada a la sección juvenil de VC desde poco antes de su secuestro, trabajaba además en una escuela en la zona oeste de la Provincia de Buenos Aires. El día que la secuestraron, estaba junto a su marido en la casa de sus suegros. A diferencia de él, permaneció un mes y medio más en el CCD, y recién recuperó su libertad en mayo de 1979, luego de casi ocho meses en el penal de Villa Devoto.

En su declaración ante el juez Ocampos, efectuada el día 6 de diciembre, Piñeiro abordó, entre otras cuestiones, las vicisitudes atravesadas en el tránsito de secuestrada clandestina a detenida legalizada:

Una noche fueron cargadas en un camión de carnes, encapuchadas y con ataduras en sus manos (...). Al tiempo, minutos quizás, llegaron personas del ejército que en el mismo camión las transportaron al Batallón $\mathrm{n}^{\circ} 10$ de Logística de Villa Martelli. Allí también le hicieron firmar una declaración que cree es réplica de la anterior [firmada en El Vesubio]. Permanecieron en el Batallón hasta el cinco de octubre en que fueron

21 En un artículo reciente, Silvina Jensen hace un interesante análisis del empleo y la valoración del instrumento judicial en la denuncia de los crímenes dictatoriales ("Los exiliados argentinos y las luchas por la justicia (1976-1981)", en Estudios, n³8, julio-diciembre 2017.).

22 Juzgado Nacional de Instrucción en lo Criminal n³, op. cit., fs. 15. 
trasladadas junto a sus amigas a la Unidad n² de Detención [de Villa Devoto] ${ }^{23}$.

Por primera vez en el marco de la causa se hacía referencia a una conexión entre el CCD y dependencias oficiales de las Fuerzas Armadas y de Seguridad. La declaración ponía así de relieve, posiblemente de manera inconsciente, una compleja trama de relaciones detrás del funcionamiento del aparato represivo clandestino según la cual existían conexiones entre el ejercicio de la represión en un marco de ilegalidad y las instituciones encargadas de llevar adelante dicha tarea dentro de los marcos impuestos por la ley.

Además de citar a las tres mujeres, el juez Ocampos llamó a declarar a Guarido, quien el 13 de diciembre de 1978 ofreció un nuevo relato sobre su experiencia en El Vesubio. Más extensa que la brindada meses atrás, esta segunda declaración incorporaba una serie de detalles novedosos. Narraba, por ejemplo, los pormenores del accionar del grupo de tareas ${ }^{24}$ durante el secuestro, denunciando el robo de dinero y de objetos de valor, adjuntando una descripción física de los secuestradores:

Con relación a estas cuatro personas, a las que el dicente podría reconocer en el supuesto caso de volver a verlas, tenían los siguientes rasgos: uno de estatura mediana, 1,70 mts o 1,75 mts, rubio con rulos, 25 años aproximadamente, delgado, vestido con vaqueros y camisa de tono azul, pelo corto; otro era robusto, 1,75 mts, morocho, 35 años aproximadamente, de bigotes espesos, vaquero azul y un pullover de tono celeste a rayas; el tercero era de estatura baja, 45 años aproximadamente, pelo corto con bigotes color negro, quien aparentemente era el que daba las órdenes, no recordando vestimenta, y el último era de unos 35 años, robusto, pelo muy corto, ojos desorbitados $(\ldots)^{25}$.

El paso del tiempo, la sedimentación de la experiencia y el esfuerzo recordatorio habían ejercido su influencia sobre el contenido del relato, sumando datos estaban ausentes en el primer e intempestivo contacto con la Justicia. Aun así, vale interrogarse sobre otros posibles motivos que, "desde afuera" del acto recordatorio, colaboraron en la incorporación de esos nuevos datos. En el transcurso de los cinco meses que mediaron entre ambas declaraciones, por ejemplo, había tenido lugar la legalización de su esposa. Este hecho posiblemente hiciera disminuir el temor de Guarido a represalias de parte de sus captores, alentándolo a agregar detalles a su relato. Por otra parte, el aumento de la presión internacional sobre la dictadura durante los meses finales del año, expresado entre otras cosas en la invitación que la Junta Militar había cursado a la CIDH, creaba un ambiente más alentador para la denuncia. Ambos factores colaboraron sin duda en la ampliación del horizonte de lo decible ${ }^{26}$.

\footnotetext{
${ }^{23}$ Juzgado Nacional de Instrucción en lo Criminal n³, op. cit., fs.69/ vta.

24 "Grupos de tareas" era la denominación utilizada para hacer referencia a los grupos encargados de realizar los secuestros de las personas que, luego, serían conducidas a alguno de los CCD dictatoriales. En la mayoría de los casos, sus integrantes también participaban de los interrogatorios bajo tortura de los cautivos.

25 Juzgado Nacional de Instrucción en lo Criminal n³, op. cit., fs.72/ vta.

26 Para más información sobre los pormenores de la invitación a la CIDH, véase véase Paula Canelo, El proceso en su laberinto. La interna militar de interna a Bignone, Buenos Aires, Prometeo, 2008; Marcos
} 


\section{Armar el rompecabezas}

Mayo de 1979 trajo consigo novedades para la causa $\mathrm{n}^{0} 35.040 / 78$, bajo la forma de nuevas declaraciones testimoniales. Los relatos, en este caso, correspondían a un grupo de cuatro hombres alojados en la Unidad Penitenciaria $n^{\circ} 9$ de la ciudad de La Plata, quienes luego de que el Consejo de Guerra declara la incompetencia sobre su caso fueron puestos a disposición de los tribunales civiles. Allí, comparecieron ante el juez Rivarola, temido por el trato que dispensaba a los detenidos, quien les tomó declaración indagatoria para establecer su participación en actividades consideradas subversivas y, en función de ello, definir su situación procesal ${ }^{27}$.

La conexión con las actuaciones del Dr. Oliveri -que motivó el envío de las declaraciones al magistrado- se fundaba en el hecho de que esos cuatro hombres habían formado parte del mismo procedimiento de legalización que Piñeiro, la esposa de Guarido. En total, habían sido siete las personas que habían atravesado las puertas del CCD en una camioneta con rumbo incierto, cuatro hombres y tres mujeres, quienes finalmente recalaron en el Batallón de Logística X de Villa Martelli, punto de partida del procedimiento de "blanqueo". Mientras que el destino final para las mujeres había sido, como ya se mencionó, el penal de Devoto, los varones fueron destinados a la penitenciaría de La Plata. En ambos casos, la estadía duró aproximadamente ocho meses, tiempo que tardaron en expedirse sobre sus casos los tribunales militares y civiles.

La primera citación fue para Jorge Watts, militante de VC desde su paso por la Facultad de Ingeniería en el año 1967, quien tenía una intensa actividad sindical producto de su trabajo como programador en la Caja de Jubilaciones de Industria, Comercio y Actividades civiles. Como parte de esa militancia gremial, había llegado incluso a ser electo Secretario General de la rama Computación de la Asociación Trabajadores del Estado (ATE). En 1977, en el marco de su activismo político, ingresó como operario a la fábrica de galletitas Bagley. Allí lo fueron a buscar el 22 de julio de 1978 los grupos de tareas para secuestrarlo y conducirlo a El Vesubio.

Watts compareció ante el juez Rivarola el 21 de mayo de 1979, exactamente un día antes de recuperar definitivamente la libertad. Su declaración aportó nuevos elementos a la investigación del Dr. Oliveri, vinculados principalmente con la ubicación del lugar de cautiverio. De este modo, el testimonio complementó los datos brindados por Guarido. La "ruta" a la que había hecho referencia éste último era, en el testimonio recién incorporado, casi con certeza "la [autopista] Ricchieri", una de las vías principales de salida e ingreso a la Capital Federal por su límite oeste. Watts, además, afirmaba que durante su cautiverio permanentemente "oía ruido de aviones" ${ }^{28}$. Este indicio, sumado al convencimiento de la

Novaro y Vicente Palermo, La dictadura militar 1976-1983: del golpe de Estado a la restauración democrática, Buenos Aires: Paidós, 2006.

${ }^{27}$ El Dr. Guillermo Rivarola era famoso entre los detenidos por la severidad de las penas dictadas, así como también por el hostigamiento explícito al que sometía a algunos de los acusados al momento de recibirlos en su despacho.

${ }^{28}$ Juzgado Nacional de Instrucción en lo Criminal n³, op. cit., fs.97. Las limitaciones a la vista impuestas por las condiciones del cautiverio en los CCD -los secuestrados, por lo general, estaban encapuchados y/o vendados- agudizaban entre los detenidos otros sentidos tales como el oído, el olfato e, incluso el tacto, 
cercanía de la autopista Ricchieri, le permitía al declarante inferir que el lugar de cautiverio posiblemente se situaba en una zona cercana al aeropuerto internacional de Ezeiza.

Según el relato, minutos después de que sus captores dejaran abandonada la camioneta en la que él junto a los otros seis secuestrados habían salido del CCD:

aparecieron miembros del Ejército, quienes lo condujeron, junto con los demás [prisioneros], al Batallón Logístico 10 de Villa Martelli. (...) una vez en el Batallón, un Capitán de nombre García le tomó una declaración en la que reprodujo totalmente lo que el dicente había firmado en el lugar de encierro. (...) luego se lo trasladó a la Comisaría de Lanús, y el mismo día a la Comisaría de Monte Grande, donde estuvo hasta el 5 de octubre, fecha en que se lo trasladó a la Unidad de La Plata ${ }^{29}$.

Los nombres propios no se restringían solamente a las rutas y aeropuertos, sino que se extendían también a las fuerzas involucradas en su secuestro, delineándose así un relato más poblado de detalles que sus predecesores en la causa. De este modo, la declaración sumaba nuevas piezas al rompecabezas represivo dictatorial: la mención de las comisarías involucraba una nueva fuerza - la PBA- al mapa de complicidades con la represión clandestina, que se sumaba al Ejército y al SPF. Aunque todavía con una circulación restringida, que posiblemente no excediera al juez y su secretario, el relato se sumaba al coro de voces contrarias a la explicación oficial sobre los crímenes dictatoriales, centrada en la figura de los "excesos" 30 . Una vez concluida la declaración de Watts, comparecieron ante el juez Rivarola los otros seis secuestrados que habían abandonado junto a él El Vesubio para iniciar el proceso de legalización.

La prolongada estancia en la cárcel legal, donde a diferencia del CCD eran permitidos los contactos entre los detenidos, dejó su impronta en las nuevas declaraciones, que evidenciaban una mayor homogeneidad que sus predecesoras. Sobre ello influía seguramente también el asesoramiento de los abogados defensores, quienes apoyándose en su conocimiento del texto legal aconsejaban estratégicamente a sus defendidos para evitar una eventual condena. Finalmente, tampoco debía descartarse el hecho de que todas las declaraciones habían sido tomadas en un lapso corto de tiempo y en un mismo juzgado, lo que permitiría suponer que los sobrevivientes fueron sometidos a preguntas similares. Esta semejanza se evidenciaba especialmente entre los varones, detenidos entonces en la Unidad 9 de La Plata, en cuyos relatos reaparecían las referencias a la Ricchieri, al sonido de los aviones, al aeropuerto de Ezeiza, entre otras informaciones. Esta reiteración, al mismo tiempo que reforzaba el carácter probatorio de los relatos, contribuía a fijar ciertas imágenes y puntos de referencia comunes a todos ellos, disminuyendo su componente individual.

Este acomodamiento de los relatos al contenido de la ley se reflejaba, por ejemplo, en la declaración de Darío Machado, un militante de VC de veintidós años que había sido secuestrado en la puerta de su casa la madrugada del día 12 de agosto de 1978 en la

circunstancia que se refleja en innumerables testimonios de sobrevivientes.

29 Juzgado Nacional de Instrucción en lo Criminal n³, op. cit., fs. 98/vta.

${ }^{30}$ Para más información sobre la doctrina de los excesos, véase Canelo, op. cit. y Novaro y Palermo, op. cit. 
localidad de Florida, en la zona norte de la Provincia de Buenos Aires, cuando volvía de jugar un torneo de ajedrez. Desde allí fue llevado directamente a El Vesubio, donde permaneció cautivo por el plazo de un mes, iniciando luego el proceso de legalización ya descripto. Al ser interrogado por el juez sobre su actividad militante, Machado afirmaba que:

no pertenece ni participó al Partido Comunista Marxista Leninista, ni a agrupación política, gremial, estudiantil, o de tipo similar, que no desarrolló actividades políticas de especie alguna, ni colaboró con organizaciones que lo hicieran, ni se prestó a la difusión o propaganda o proselitismo de organizaciones o personas cuyos fines ideológicos fueran alterar o suprimir el orden institucional o la paz social de la Nación, ni participó personalmente en actividades de esa índole, ni tuvo material referido a ellas, ni colaboró en la recolección de fondos para grupos o personas que se dedicaran a este tipo de actividades. Que ignora las causas por las que se lo vinculó a este tipo de actividades $(\ldots)^{31}$.

La negación de la actividad política ya no aparecía formulada de modo genérico, como en la declaración de Guarido, sino que abarcaba toda una serie de prácticas que iban desde la participación en diversas instancias organizativas, pasando por el proselitismo y el reparto de propaganda, hasta la mera posesión de material perteneciente a organizaciones consideradas subversivas. Incluso el léxico empleado era diferente: se hablaba de "alterar o suprimir el orden institucional o la paz social de la Nación”. Se trataba de fórmulas a todas luces ajenas al universo de sentidos políticos de la militancia revolucionaria al que pertenecía el autor de la declaración.

Estas expresiones, en cambio, resultaban menos extrañas al ser leídas a la luz de la legislación antisubversiva de la época. La ley n²0.840/ 74 establecía en su artículo $1^{\circ}$ que:

Será reprimido con prisión de tres a ocho años (...) el que para lograr la finalidad de sus postulados ideológicos, intente o preconice por cualquier medio, alterar o suprimir el orden institucional y la paz social de la Nación, por vías no establecidas por la Constitución Nacional y las disposiciones legales que organizan la vida política, económica y social de la Nación ${ }^{32}$.

Así rezaba, a su vez, el artículo no 2:

ARTICULO $2^{\circ}-$ Se impondrá prisión de dos a seis años:

a) $\mathrm{Al}$ que realice actos de divulgación, propaganda o difusión tendiente al adoctrinamiento, proselitismo o instrucción de las conductas previstas en el artículo $1^{\circ}$; (...)

c) Al que tenga en su poder, exhiba, imprima, edite, reproduzca, distribuya o suministre, por cualquier medio, material impreso o grabado, por el que se informen o

31 Juzgado Nacional de Instrucción en lo Criminal n³, op. cit., fs. 108.

${ }^{32}$ Honorable Congreso de la Nación, "Ley 20.840/ 74". Disponible en www.infoleg.gov.ar (última consulta: $1 / 2 / 2018)$. 
propaguen hechos, comunicaciones o imágenes de las conductas previstas en el artículo $\mathrm{n}^{\mathrm{o}} 1(\ldots)^{33}$.

En sus trabajos sobre los procesos inquisitoriales, Carlo Ginzburg demostró cómo, a pesar de sus objetivos contrapuestos, tanto funcionarios judiciales como acusados se mueven dentro del universo de los tipos penales establecidos: unos para hacer encajar en esas fórmulas conocidas a los acusados, y los otros para evadir las tipologías penales y demostrar así su inocencia ${ }^{34}$. Los textos de las declaraciones se convierten, así leídos, en "un sutil juego de amenazas y miedos, de asaltos y retiradas" que no es sino el producto de la "relación específica, de profunda desigualdad", que media entre acusadores y acusados ${ }^{35}$. Salvando las distancias enormes entre ambos contextos históricos, el ambiente en el que se produjeron las declaraciones de los sobrevivientes podría concebirse de una manera análoga a los casos estudiados por Ginzburg. Desde esta óptica, la superficie pretendidamente lisa de la declaración mecanografiada cobra otra densidad, y lo que parece un triunfo palmario del universo de sentidos antisubversivo -esto es, la similitud entre la declaración y el texto legal- se convierte en un indicio de una disputa que subyace al acto mismo de testimoniar.

Las declaraciones ante el juez Rivarola cerraron otro capítulo en la investigación judicial por los crímenes de El Vesubio. Pasarían tres años hasta que se incorporaran nuevos testimonios a la causa. El contexto entonces sería otro, signado por el declive del régimen ante la derrota en la Guerra de Malvinas de junio de 1982 y el fortalecimiento de la oposición local e internacional. El estancamiento de las actuaciones, sin embargo, no implicó un freno en la denuncia de los crímenes cometidos en El Vesubio, sino todo lo contrario. Apelando a estrategias variadas, un segmento de los sobrevivientes de VC aprovecharía los resquicios del régimen para echar luz sobre la maquinaria represiva. Contarían para ello con el apoyo de lo que quedaba en pie de las estructuras del partido, de los familiares de sus compañeros desaparecidos y de algunos organismos de derechos humanos de la escena local.

\section{Un espacio de acción colectiva en dictadura}

\section{Vanguardia Comunista: los sobrevivientes y el partido ante la represión}

Al momento de ser secuestrado, Guillermo Lorusso repartía su tiempo entre la militancia en VC y su trabajo como contador en una fábrica de vidrios en el barrio porteño de Villa Crespo. En la madrugada del sábado 19 de agosto de 1978, se encontraba en su casa junto a un compañero del partido cuando un grupo de civiles armados irrumpió en su domicilio. Ambos fueron encapuchados y subidos a un auto, que inmediatamente arrancó con rumbo desconocido. Tiempo después sabrían que el lugar al que habían sido llevados

\footnotetext{
${ }^{33}$ Ididem.

${ }^{34}$ Carlo Ginzburg, "Microhistoria: dos o tres cosas que sé de ella", en El hilo y las huellas. Lo verdadero, lo falso, lo ficticio. Buenos Aires: Fondo de Cultura Económica, 2014.

35 Ginzburg, op. cit., p.404.
} 
era El Vesubio ${ }^{36}$. Luego de un extenso derrotero que incluyó el paso por el Regimiento I de Ciudadela y una estadía prolongada en el penal de La Plata, Lorusso salió en libertad provisoria a fines de mayo de 1979. Al poco tiempo retomó su actividad política en VC, aunque abocado principalmente a labores vinculadas con la defensa de los derechos humanos que, según recuerda, se convirtió en su "frente de tareas, de militancia, principal" 37 .

Similar fue el recorrido seguido por Watts, liberado del penal de La Plata en una fecha cercana a Lorusso. Una vez en libertad retomó el contacto con las estructuras partidarias, pero decidido a cambiar el eje de su militancia. Así recuerda la conversación mantenida entonces con sus compañeros en las filas de VC:

le planteo a los camaradas que yo ya no quiero seguir militando en el partido, sino que quiero militar exclusivamente en derechos humanos. Al ver que [VC]era a esa altura una organización pequeña y fragmentada y muy lastimada, yo prefería trabajar en un ámbito donde pudiera ser más útil. Con todo el cariño, diciendo que yo iba a seguir siendo colaborador, amigo, en lo que quisieran y para lo que necesitaran pero que iba a laburar en derechos humanos. Esa decisión la tomé en mayo del ' $79{ }^{38}$.

La militancia en clave humanitaria, si bien se corría del horizonte revolucionario trazado por VC, no era una nota disonante en la tradición partidaria. Desde comienzos de la década del setenta, la organización se había abocado a ese tipo de práctica cuando, inmediatamente después del Cordobazo, se produjo el florecimiento de las llamadas "comisiones de presos" producto del aumento de la persecución de los militantes sindicales. Dentro del amplio universo de estas agrupaciones, VC tuvo una estrecha relación con la Organización de Solidaridad con los Presos Políticos, Estudiantiles y Gremiales $\left(\right.$ OSPPEG) ${ }^{39}$.

La dictadura militar iniciada en Argentina en marzo de 1976, con la feroz represión ejercida hacia toda forma de disidencia política, no hizo sino consolidar esta arista partidaria. Desde la clandestinidad, No transar -periódico oficial de VC- difundía los lineamientos de acción centrales para la nueva etapa, que se resumían en: “ $1{ }^{\circ}$ ) agrupar familiares de presos y desaparecidos, $2^{\circ}$ ) divulgar, denunciar toda detención y secuestro, $3^{\circ}$ ) aprovechar las armas legales: hábeas corpus, pedidos de informes, etc. (sic), $4^{\circ}$ ) organizar la solidaridad con los presos incluyendo petitorios (...) y así parar la represión"40. En este sentido, VC seguía la línea de otras fuerzas políticas que, ante la crudeza de la represión, habían dejado en un segundo plano su estrategia de lucha revolucionaria para

\footnotetext{
36 Reconstrucción realizada a partir de conversaciones con Guillermo Lorusso y de la lectura de su declaración testimonial en la causa $\mathrm{n}^{\circ} 35.040 / 78$.

${ }^{37}$ Guillermo Lorusso, entrevista con el autor, Ciudad Autónoma de Buenos Aires, 13 de julio de 2015.

38 Jorge Watts, entrevista con el autor, Ciudad Autónoma de Buenos Aires, 21 de noviembre de 2014.

39 Ana Carol Solís, "De las comisiones a los organismos en Córdoba: derechos humanos, dictadura y democratización”, en Rubén Isidoro Kotler (comp.), En el país del sí me acuerdo. Los orígenes nacionales e internacionales del movimiento de derechos humanos argentino: de la dictadura a la transición, Buenos Aires, Imago Mundi, 2014.

${ }^{40}$ Américo Soto, Vidas y luchas de Vanguardia Comunista, Buenos Aires, Ediciones Nuevos Tiempos, 2004, p.4.
} 
concentrar sus fuerzas en la actividad de denuncia de las violaciones a los derechos humanos, fenómeno particularmente visible en el terreno del exilio ${ }^{41}$.

Esta estrategia de denuncia en clave humanitaria se potenció sobre todo a partir del fuerte golpe que la dictadura propinó al partido durante el segundo semestre de 1978, con el secuestro de prácticamente toda la plana mayor de su dirigencia, generando así una crisis mayor al interior de VC. Inés Vázquez, por entonces una joven militante de dieciséis años que había permanecido secuestrada en El Vesubio junto a sus dos hermanos, rememora el panorama partidario con el que se encontró luego de ser liberada del CCD:

No había [estructuras partidarias]. Más que yo había empezado a militar durante la dictadura; en el año 78 yo tenía dieciséis años. Había empezado un poquito antes, en el '77, '76. Mi responsable estaba desaparecido; mi hermano, que estaba en la juventud, estaba desaparecido (...). Entonces, tal vez conocía muy poca gente. Y después que de esta organización [VC] fue secuestrado hasta el Secretario General, Roberto Cristina (Inés Vázquez, entrevista con el autor, Ciudad Autónoma de Buenos Aires, 9 de abril de 2015.

La sensación transmitida en el fragmento fue la de muchos militantes jóvenes de VC que, una vez liberados de El Vesubio, intentaron retomar contacto con las estructuras partidarias: ante la desaparición de muchos de los cuadros de mayor responsabilidad, estos activistas de menor trayectoria en una situación de aislamiento, dada la persecución imperante y la consecuente clandestinidad que envolvía por entonces la militancia.

Ante esta situación, en un esfuerzo por contrarrestar la desintegración partidaria, "viajaron del interior del país algunos dirigentes que reconstruyeron la regional, la dirección de la regional en Buenos Aires, que había quedado diezmada"42. Como parte de este intento de reconstrucción de $\mathrm{VC}$, se iniciaron gestiones para designar a un nuevo Secretario General, cargo que sería finalmente ocupado por Mario "el Nato" Geller. Mientras este ensayo de recuperación se llevaba adelante, con las dificultades que imponía a esta tarea la represión orquestada desde el régimen militar, lo que restaba del partido ofició de espacio de encuentro para los sobrevivientes y los familiares de los desaparecidos de El Vesubio. Fueron los primeros pasos para la confección de un colectivo de denuncia en plena dictadura.

\footnotetext{
41 Para más información sobre este viraje desde una lógica política revolucionaria hacia una de carácter humanitario, véase Franco, 2008, op. cit.; Jensen, 2010; op. cit; Vania Markarian, Idos y recién llegados. La izquierda uruguaya en el exilio y las redes transnacionales de derechos humanos, 1967-1984, Montevideo: Correo del Maestro, 2006.

${ }^{42}$ Guillermo Lorusso, entrevista con el autor, 13 de julio de 2015, op. cit.
} 


\title{
La articulación con los familiares
}

En su edición del 25 de enero de 1979, el diario La Nación publicó la siguiente solicitada:

¿DÓNDE ESTA?

\author{
AL EXCMO. PRESIDENTE DE LA NACIÓN \\ A LA JUNTA MILITAR \\ A LA JUSTICIA ARGENTINA \\ A LA PRENSA EN GENERAL Y \\ A LA OPINIÓN PÚBLICA
}

Han transcurrido 5 largos meses de la desaparición de mi querido hijo y aún no he tenido noticia alguna.

Habiendo agotado todas las instancias legales sin obtener respuestas positivas hago un llamado por él con la esperanza que puedan ayudarme a encontrarlo sano y salvo.

ROBERTO CRISTINA (...) desaparecido el 15/8/78.

Esta solicitada ha sido costeada con el aporte de familiares y amigos ${ }^{43}$.

En una lectura literal, la publicación, que llevaba la firma de Antonia Cristina, parecía responder al impulso de una madre que pretendía conocer el paradero de su hijo desaparecido. El pedido, en efecto, se limitaba a la aparición con vida - "sano y salvo" - de Roberto Cristina, sin hacer referencia alguna a su militancia: según el texto de la solicitada, era un "querido hijo" buscado por su madre y no el líder de un partido revolucionario. Y el dinero para la publicación, el producto del "aporte de familiares y amigos" y no de la colaboración de su espacio de militancia. Incluso el encabezado, dirigido a un amplio y heterogéneo espectro de interlocutores, desdibujaba las responsabilidades detrás de la desaparición.

Sin embargo, detrás del contenido evidente de la publicación se ocultaba un entramado más complejo y con una densidad política mayor que el reclamo de una madre ante la desaparición de su hijo. En primer término, Antonia Cristina no era una persona que ignorara el contexto represivo de la época: la mujer había sufrido ya la desaparición de una de sus hijas, Eleonora -militante del Partido Revolucionario de los Trabajadores-Ejército Revolucionario del Pueblo (PRT-ERP), el 16 de marzo de 1975. A ello se agregaba que tampoco desconocía la actividad política de su hijo Roberto, sino que, al contrario, tenía fluidos contactos con sus compañeros de VC. Lo que el documento más bien reflejaba, entonces, eran las limitaciones a las que se enfrentaban quienes pretendían denunciar públicamente las atrocidades del régimen militar y, ante esas dificultades, las estrategias a las que recurrían para hacer oír su reclamo a pesar de los obstáculos que planteaba la dictadura $^{44}$.

${ }^{43}$ La Nación, 25 de enero de 1979.

${ }^{44}$ La solicitada que reclamaba por la aparición de Roberto Cristina había sido precedida por otra publicada un día antes en el periódico La Prensa, presentando ambas una similitud que dejaba pocas dudas respecto de su origen común. A diferencia del escrito aparecido en La Nación, el reclamo ya no se circunscribía solamente a 
En Vidas y luchas de Vanguardia Comunista, Américo Soto hace hincapié en el énfasis otorgado por el partido a la denuncia humanitaria, y de los vínculos establecidos a esos fines con los familiares de sus militantes desaparecidos. Así, sostiene que, luego del golpe, "una orientación clave de VC fue la de promover la organización de los familiares de los desaparecidos y detenidos" "45, lo que llevó a que tempranamente muchos de sus militantes se incorporaran a trabajar con el naciente movimiento de derechos humanos local. Lorusso fue uno de los protagonistas de estos contactos. A casi cuatro décadas de esos sucesos, recuerda cómo los sobrevivientes del partido fueron tejiendo lazos con los familiares de los compañeros de militancia desaparecidos:

(...) hubo una etapa que era la etapa de los familiares. De los familiares y de los que habíamos salido [de El Vesubio] que nos veníamos juntando. Podíamos ser veinte personas, los más activos. Quince, veinte personas (...). Después, esta Comisión se va desprendiendo de los familiares; los familiares por lo general eran gente de edad, y es gente que fue falleciendo. (...) va sucediendo por una cuestión generacional, toda gente grande. Y se va incorporando otra gente ${ }^{46}$.

El contexto de persecución de la época y las propias características de aislamiento que planteaba el dispositivo de secuestro clandestino definieron con precisión las fronteras de esa labor conjunta entre sobrevivientes y familiares durante esa primera etapa:

de la vinculación con los familiares surge la necesidad de hacer un trabajo en común para hacer solicitadas, declaraciones, firmar los requerimientos jurídicos. Entonces, en principio es totalmente del partido, una comisión de familiares que técnicamente no es una Comisión de Vesubio sino una Comisión de detenidos-desaparecidos, de víctimas del partido de Vesubio. Donde estábamos los treinta y cinco que salimos [en septiembre de 1978, para ser legalizados], y los familiares de los diecinueve que permanecían desaparecidos ${ }^{47}$.

El vínculo con VC fue para familiares y sobrevivientes un punto de referencia común y un elemento aglutinador de esfuerzos en un ambiente de persecución que reforzaba las tendencias hacia el aislamiento. Los contornos partidarios, de este modo, constituyeron los límites dentro de los cuales se movió el reclamo por la suerte de los desaparecidos de El Vesubio durante las primeras iniciativas de denuncia, ante las dificultades emanadas de la coyuntura política.

En un inicio el grupo adoptó como sede de sus reuniones la casa de Antonia Cristina. Estos encuentros, en los que se diseñaban estrategias para llevar adelante el reclamo por el paradero de los militantes del partido desaparecidos, consolidaron poco a poco un colectivo de denuncia que, aunque de naturaleza informal, trascendió en su labor las fronteras

la figura de Cristina, sino que sumaba al pedido de reaparición los nombres de Jorge Montero y Abraham Hochman, cuadros importantes de VC. Exceptuando este agregado, el texto -que no tenía firma- era idéntico al de la solicitada a cargo de Antonia Cristina, evidenciando su concepción conjunta.

45 Soto, op. cit., p.72.

${ }^{46}$ Guillermo Lorusso, entrevista con el autor, op.cit.

${ }^{47}$ Ibidem. 
nacionales, al entablarse contacto con los sobrevivientes del partido exiliados, cuyos testimonios fueron ingresados clandestinamente al país y luego utilizados para diversas presentaciones judiciales ${ }^{48}$. Para realizar éstas y otras iniciativas públicas de denuncia, fue fundamental la articulación con un actor central en la lucha antidictatorial: el movimiento de derechos humanos local.

\section{El vínculo con los organismos de derechos humanos}

Durante la dictadura, en línea con la ya mencionada estrategia partidaria, VC tendió puentes con diversos organismos locales. Uno de los primeros vínculos fue el que se forjó con la entonces incipiente organización Madres de Plaza de Mayo (Madres). En relación con este contacto, Lorusso recuerda que "los compañeros y compañeras [de VC] a principios del '77 son los que acompañaban a las madres cuando Madres todavía no se había formado", participando de las reuniones formativas del organismo ${ }^{49}$. Prueba de estas relaciones entre el organismo y el partido es el hecho de que dentro del grupo de Madres secuestrado en la puerta de la Iglesia de la Santa Cruz en diciembre de 1977 se encontraran cinco militantes de $\mathrm{VC}^{50}$. El duro golpe ocasionado por estos secuestros, denunciados oportunamente desde la prensa partidaria, no trajo aparejado, sin embargo, el final de la política humanitaria del partido ${ }^{51}$. Ni siquiera cuando, en el transcurso del año siguiente, la organización se convirtiera en uno de los blancos privilegiados de los grupos de tareas con sede en El Vesubio.

Familiares de Desaparecidos y Detenidos por Razones Políticas (Familiares) fue otro de los organismos con los que se relacionaron los sobrevivientes de VC. Lorusso, encargado por el partido del vínculo con dicha entidad, recuerda cómo fueron esos primeros contactos:

En principio, en el año '79, '80, '81, '82, '83 mismo yo desarrollé la actividad de derechos humanos en Familiares de Desaparecidos y Detenidos por Razones Políticas, que actuaba en la sede de la Liga Argentina por los Derechos del Hombre. No tenía sede propia, actuaba allí en el piso segundo, tercero, quinto. Eran dos veces por semana: un día se dedicaba a desaparecidos y otro, a presos políticos ${ }^{52}$.

Este trabajo con los organismos, que funcionaba en condiciones de precariedad emanadas del contexto dictatorial pero también producto de dificultades de orden material, se orientaba a dos tipos de tareas fundamentales además de la contención de los familiares, que era una labor prioritaria. Por un lado, el accionar vinculado al campo jurídico. En este plano reaparecía esa ambivalencia entre la desconfianza hacia el Poder Judicial y la

\footnotetext{
${ }^{48}$ Reconstrucción realizada en base a las entrevistas del autor con Jorge Watts y Guillermo Lorusso.

${ }^{49}$ Guillermo Loruso, entrevista con el autor, op.cit.

${ }^{50}$ Los militantes de VC secuestrados en la Iglesia Santa Cruz fueron Angela Aguad, Patricia Oviedo, Eduardo Gabriel Horane, Horacio Aníbal Elbert y Raquel Bulit (Soto, op. cit., p.72). Todos ellos se encuentran desaparecidos. Otra militante del partido, Cecilia Vázquez, evitaría casi por casualidad su secuestro, relatando su odisea al periodista francés Jean-Pierre Bousquet durante su exilio en ese país.

${ }^{51}$ Para más información, véase No transar n ${ }^{\circ} 203$ y 204.

52 Guillermo Lorusso, entrevista con el autor, 13 de julio de 2015, op. cit.
} 
necesidad de dejar constancia legal de los crímenes: "nosotros jamás confiamos en los jueces", recuerda Lorusso, "pero era un frente de batalla en el que teníamos que desarrollar nuestra lucha y la desarrollábamos"53. El otro campo al que se volcó el accionar conjunto de sobrevivientes, familiares y organismos de derechos humanos fue la visibilización de los crímenes de la represión dictatorial más allá de los tribunales, y que comprendía "todo lo que era estrictamente político", como "las solicitadas, los homenajes, las reuniones, los actos" $" 54$.

Nacido como un desprendimiento de la Asamblea Permanente por los Derechos Humanos (APDH), el CELS se planteó desde el comienzo la vía judicial como el instrumento privilegiado en su lucha contra la dictadura. Pero la tarea de investigación desplegada no se redujo sólo a aportar evidencia a la Justicia, sino también a producir informes y declaraciones donde se denunciaban los crímenes de la represión en Argentina. De este modo, se pretendía visibilizar la represión fuera del país para obtener la condena internacional de la dictadura. El organismo resultaría fundamental para dotar de un encuadre jurídico a las denuncias de los sobrevivientes y familiares de desaparecidos de VC, asesoramiento que tempranamente daría sus frutos.

El 1 de agosto de 1980, una delegación conformada por abogados del CELS y por sobrevivientes y familiares de desaparecidos de VC acercó a la Justicia un reclamo judicial por los secuestros de militantes del partido ocurridos durante julio y agosto de 1978. La presentación dio origen a nuevas actuaciones: la causa $\mathrm{n}^{\circ} 15.807 /$ 80. La acción del colectivo forjado en torno a VC tuvo eco, aunque todavía de manera limitada, en los medios locales. El diario La Prensa, en su edición del 29 de agosto, publicó una nota titulada "Denuncia por privación ilegal de la libertad":

Familiares de 15 personas que desaparecieron -según se afirma- entre el 18 de julio y el 17 de agosto de 1978, formularon ante la justicia una denuncia por "privación ilegal de la libertad" y ofrecieron el testimonio de ocho personas radicadas en el exterior, según informaron. Se afirma que las ocho personas ofrecidas como prueba testimonial "fueron compañeros de cautiverio de nuestros familiares".

La denuncia quedó radicada en el Juzgado en lo Criminal de Instrucción 19, del doctor Miguel Ángel Caminos, Secretaría 159, del doctor Rodolfo Ricotta Denby y contiene un anexo con los testigos ofrecidos, cuyos textos no se conocieron y cuya reserva se solicitó en la caja de seguridad del tribunal ${ }^{55}$.

La presentación, formulada colectivamente, estaba auspiciada por un conjunto de abogados del organismo y de diversas personalidades vinculadas al universo de los derechos humanos. A pesar del carácter colectivo del escrito, los denunciantes no hacían referencia a la existencia del grupo constituido en torno a VC, sino que fundamentaban su acción conjunta en un mero "principio de economía procesal". Para apoyar este reclamo citaban los testimonios de los sobrevivientes del partido exiliados en diversos países de Europa, que se incluían adjuntos a la presentación. De estos relatos se desprendía, de

\footnotetext{
${ }^{53}$ Ibidem.

${ }^{54}$ Ibidem.

${ }^{55}$ La Prensa, 29 de agosto de 1980.
} 
acuerdo con los autores del documento, que todos los secuestros incluidos en el escrito habían sido realizados "por un conjunto de personas cuyo accionar y móviles, su grado de permanencia y su organización" era compatible con "la existencia de una asociación ilícita" 56 . No se incluían, por motivos obvios, referencias a los relatos producidos por sobrevivientes dentro de las fronteras nacionales.

Entre los testimonios agregados a la denuncia se encontraba el de Cecilia Vázquez, una estudiante de Psicología y militante de VC secuestrada de su domicilio familiar el 19 de julio de 1978, junto a su hermana Inés. Ambas fueron llevadas a El Vesubio, donde permanecía secuestrado su hermano. Legalizada en el penal de Villa Devoto, recuperó su libertad al año siguiente. Luego de ello, partió al exilio con destino a Francia. Su testimonio, procedente de ese país europeo, estaba fechado el 6 de octubre de 1979. Allí, por primera vez, el lugar de cautiverio aparecía mencionado con el nombre que le habían otorgado los represores:

Este campo de interrogación y concentración funciona como empresa "El Vesubio", sección La Matanza, según tarjetas impresas cercanas a un fichero en el lugar donde esperábamos para ir al baño. Sus responsables lo catalogan como "chupadero", donde tienen a la gente "chupada" (secuestrada). Está situado camino a Ezeiza, cercano a la ruta Richieri, desde una ventana tapiada se ve pasar el ómnibus 86. Es un conjunto de tres casas (...), sé que más allá había una pileta de natación. Hay árboles, se oyen pájaros, trenes, aviones, los autos de la ruta ${ }^{57}$.

Las pruebas aportadas por los testimonios de los sobrevivientes y la repercusión mediática de la denuncia no fueron suficientes para que la iniciativa legal prosperara en los pasillos judiciales: el 30 de septiembre de ese año 1980, el juez Caminos puso un freno a las actuaciones. Amparándose en legislación sancionada durante la dictadura -la ley n²1.267 establecía que quedaba bajo jurisdicción de los tribunales militares cualquier ilícito cometido por personal de las Fuerzas Armadas en cumplimiento de actos de servicio-, el magistrado declaraba su incompetencia para tratar la causa. A diferencia de lo que había ocurrido dos años antes con la denuncia ante el juez Oliveri, en este caso el magistrado se apegaba a lo "normal cotidiano" de la época.

El revés judicial no detuvo el accionar del colectivo forjado en torno a VC. Ese mismo año, el CELS publicaría su "Informe sobre la situación de los derechos humanos en Argentina", que abarcaba el período comprendido entre octubre de 1979 y el mismo mes de 1980. Un apartado del documento, titulado "Testimonios ofrecidos en el exterior", reivindicaba el papel de los "testimonios de personas que recuperaron su libertad después de pasar períodos más o menos largos en calidad de desaparecidos” en la reconstrucción del dispositivo represivo, así como también en "la localización de varios centros clandestinos de detención" y en la identificación de las fuerzas a cargo de ellos ${ }^{58}$. Un párrafo en particular estaba dedicado a "un grupo de personas actualmente exiliadas", secuestradas "entre julio y

\footnotetext{
56 Juzgado Nacional de Instrucción en lo Criminal n³, op. cit., fs.358.

57 Juzgado Nacional de Instrucción en lo Criminal n³, op. cit., fs.390.

${ }^{58}$ Centro de Estudios Legales y Sociales, "Informe sobre la situación de los derechos humanos en Argentina", 1980 , p. 17.
} 
agosto de 1978" junto a media centena de compañeros de militancia, pertenecientes a "una agrupación política no subversiva". El texto dejaba pocas dudas de que la organización referida era $\mathrm{VC}^{59}$. La aclaración final, a su vez, daba cuenta de la fuerza del imaginario político antisubversivo en el espacio público de la época, cuya influencia se hacía sentir tanto dentro como fuera de la Argentina.

Dos años después, en 1982, el organismo publicó un nuevo documento dedicado por entero a los secuestros de militantes de VC en El Vesubio. Titulado "Un caso judicial revelador", el escrito comenzaba señalando que:

Entre mediados de julio de 1978 y mediados de agosto del mismo año, Fuerzas de Seguridad procedieron al secuestro de aproximadamente 68 personas, bajo la acusación de pertenecer a un determinado grupo político marxista-leninista. Quince de estos secuestrados (...) fueron puestos en libertad, en forma no oficial, abandonándoselos en la vía pública (...). Otras treinta y cuatro personas, después de pasar más de un mes en un "chupadero", fueron depositados en grupos de siete en diferentes lugares maniatados y encapuchados dentro de un vehículo- para ser recogidos, al cabo de unos pocos minutos, por efectivos del Ejército que los condujeron detenidos a dependencias policiales o militares. Algunas semanas más tarde se avisaría a sus familiares y serían oficialmente legalizados. Se los sometió a Consejo de Guerra, el que remitió las causas a la Justicia Ordinaria. Por último diecinueve personas, aún hoy, permanecen en situación de detenidos-desaparecidos ${ }^{60}$.

Detrás de esta insistencia en el caso de VC posiblemente se escondieran, además de las convicciones humanitarias del organismo, motivos de orden práctico y estratégico. Por un lado, como decía el mismo informe, "contrariamente a lo que suele ocurrir con el relato de secuestros de personas detenidas-desaparecidas", en el caso de El Vesubio se podía aseverar que "estaban casi todas las piezas del rompecabezas" represivo ${ }^{61}$ : el nombre del $\mathrm{CCD}$, su ubicación, las fuerzas responsables de su funcionamiento, entre otros elementos, habían sido reconstruidos a partir de los testimonios recogidos entre los sobrevivientes del partido. En consecuencia, se trataba de un caso que, como pocos otros, permitía ilustrar las diversas responsabilidades involucradas en la tarea represiva. Al mismo tiempo, El Vesubio constituía un ejemplo privilegiado de lo que Augusto Conte y Emilio Mignone, miembros fundadores del CELS, habían denominado doctrina del "paralelismo global". Según esta teoría, el aparato represivo constaba de "dos niveles de normatividad", uno de carácter público, "compuesto por el conjunto de normas sancionadas antes y después del 24 de marzo de 1976"; y el otro secreto, basado en el secuestro, cautiverio clandestino y desaparición de personas ${ }^{62}$.

"Un caso judicial revelador" destacaba, además, la particularidad que rodeaba a los sobrevivientes de VC y su centralidad para la reconstrucción del dispositivo represivo clandestino. Un pasaje del documento señalaba, en este sentido, que "por primera vez se ponía en libertad a un grupo importante de personas que habían podido conocer y

\footnotetext{
${ }^{59}$ Ididem.

${ }^{60}$ Centro de Estudios Legales y Sociales, “Un caso judicial revelador”, 1982, p.4.

${ }^{61}$ Centro de Estudios Legales y Sociales, op. cit, 1982, p.17

${ }^{62}$ Emilio Fermín Mignone y Augusto Conte Mc Donnell, "La doctrina del paralelismo global”, 1981, p.1
} 
confrontar entre ellos, aspectos fundamentales del sistema represivo paralelo"63. Esta especificidad hacía de El Vesubio en uno de los ejemplos más documentados del funcionamiento la represión durante la dictadura militar, a la par de CCD de mayor envergadura, como por ejemplo la ESMA o La Perla.

El texto finalizaba afirmando que "en los meses siguientes" a las liberaciones, los "testimonios completos" de los sobrevivientes de El Vesubio tomaban estado público en el país, o en el exterior", circunstancia que daba cuenta en realidad de un fenómeno mayor que incluía relatos procedentes de diversos lugares del país ${ }^{64}$. Apoyados en las redes transnacionales de denuncia montadas por los organismos de derechos humanos locales e internacionales, los testimonios de los sobrevivientes del cautiverio clandestino alcanzaban cada vez una mayor difusión pública. Estos relatos dieron lugar a la configuración de diversos "circuitos testimoniales" entre los cuales los relatos de los sobrevivientes de El Vesubio constituían sólo un ejemplo ${ }^{65}$.

\section{La mirada puesta en El Vesubio}

\section{Atando cabos}

Al comenzar 1983, el final del régimen militar y la vuelta de la democracia se avizoraban como un horizonte posible: el desprestigio de la Junta Militar había aumentado de manera exponencial tanto dentro como fuera de la Argentina debido a sucesos puntuales -tales como la publicación del Informe de la CIDH sobre su visita al país o el fracaso militar en la guerra de Malvinas- y como producto del devenir de la propia situación económica local, que se deterioraba a medida que avanzaba la dictadura. En medio de un clima de renacimiento de la política partidaria y de creciente movilización social contra la dictadura,que había obligado a los militares a evaluar diversas alternativas para su salida del gobierno ${ }^{66}$, las actuaciones por los crímenes de El Vesubio salieron de su letargo.

En los primeros días de marzo, una nueva serie de declaraciones testimoniales se

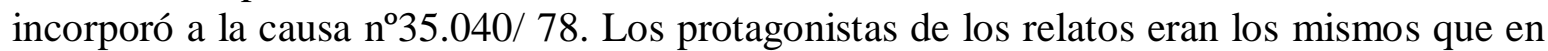
los años anteriores, el grupo de siete sobrevivientes legalizados conjuntamente en septiembre de 1978. Para Darío Machado, por ejemplo, era la tercera presentación ante los tribunales civiles, aunque la primera frente a Oliveri:

reconstruyendo datos y "atando cabos" con otros detenidos, con posterioridad a su liberación, concluyeron que el lugar de detención se hallaría ubicado en las inmediaciones de Camino de Cintura y Autopista Ricchieri. Ello se debe a comentarios efectuados entre sí por sus captores, coincidentes por la fugaz visión lograda desde su

\footnotetext{
${ }^{63}$ Centro de Estudios Legales y Sociales, op. cit., 1982, p.14.

${ }^{64}$ Ibidem.

${ }^{65}$ González Tizón, op.cit, 2016.

66 Véase Canelo, op.cit; Marina Franco, "Los derechos humanos en los años 80 dictatoriales: un viejo problema bajo nuevas preguntas", ponencia presentada en las VII Jornadas de Trabajo sobre Historia Reciente, Rosario, Facultad de Humanidades, 2016.
} 
cautiverio con otro de los detenidos ${ }^{67}$.

La cuestión de la ubicación del CCD, tópico ya visitado en el expediente judicial, incorporaba un detalle fundamental para la comprensión del recorrido hacia la identificación del lugar de detención: los contactos establecidos entre los sobrevivientes una vez liberados. El cruce de las diversas experiencias de cautiverio había hecho posible, a partir de los retazos de información acumulados por cada uno durante su estadía en El Vesubio, reunir un conjunto de indicios que apuntaban a un punto preciso del mapa. Nuevamente, sin ser mencionado explícitamente, el colectivo formado en torno a VC $-\mathrm{y}$ dentro del mismo, los sobrevivientes- se evidenciaba como una pieza clave en la reconstrucción del aparato represivo clandestino.

Otro componente novedoso de esta nueva serie de declaraciones lo constituían las descripciones del interior del lugar de cautiverio, ausentes en los testimonios judiciales previos. En una nueva declaración que ampliaba su relato precedente, Watts afirmaba que:

el lugar en el que permaneció, junto con otros compañeros de cautiverio, durante unos cincuenta días, era un predio con tres casas tipo chalet. La denominada casa $n^{\circ} 1$ estaba destinada al asiento de la jefatura o comandancia. El lugar llamado "casa n 2 " era el lugar de torturas y alojamiento transitorio, y la casa $\mathrm{n}^{\circ} 3$ era un alojamiento donde pasaban los detenidos tras los duros interrogatorios practicados en la casa $n^{\circ} 2^{68}$.

La reconstrucción de la espacialidad del CCD se veía acompañada, además, de una recuperación de los nombres y la funcionalidad de cada una de las edificaciones que lo componían. De este modo, las declaraciones permitían asomarse a la dinámica interna de El Vesubio, repartida entre las tres casas que configuraban el lugar de detención. La mutación operada en el plano de la política nacional, que hacía de la democracia una posibilidad tangible y del proceso a los represores un horizonte menos utópico que cuatro años atrás, sin duda operaba también favoreciendo una ampliación de las fronteras de lo decible por parte de los sobrevivientes.

Como parte de esta descripción interna del CCD se incluía información más detallada en torno a la dependencia orgánica de El Vesubio. Así, en su declaración ante Oliveri, Machado afirmaba que:

la participación del Ejército en las tareas de detención e interrogatorio de prisioneros en ese sitio la concluye a partir de diversas pautas, a saber: en los platos y tazas de lata que les servían para ingerir alimentos se podía leer, mirando al sesgo por debajo de la capucha, la inscripción "Ejército Argentino"; en varias oportunidades, observó a través de la capucha (...) a uniformados -suboficiales- del Ejército con armas largas. Jorge Watts reconoció a un oficial que presenció los "interrogatorios" en el sitio descripto ["casa 2"], al que visualizó del modo antes indicado, como el mismo que los recibió en el Escuadrón 601 [en referencia al Batallón de Logística X]de Villa Martelli69.

\footnotetext{
${ }^{67}$ Juzgado Nacional de Instrucción en lo Criminal n³, op. cit., fs.210.

${ }^{68}$ Juzgado Nacional de Instrucción en lo Criminal n³, op. cit., fs.218.

${ }^{69}$ Juzgado Nacional de Instrucción en lo Criminal n³, op. cit., fs.210.
} 
Insumos de la vida cotidiana o el reconocimiento de personal del CCD en dependencias oficiales del Ejército funcionaban como refuerzos de la hipótesis sobre la existencia de vasos comunicantes entre la represión clandestina y su contraparte legal. Esta evidencia contradecía todavía con más fuerza la doctrina de los supuestos "excesos" como causa eficiente de los secuestros, las torturas, los asesinatos y las desapariciones, y abonaba en su lugar la idea de que la represión clandestina era el resultado de un plan impulsado desde las estructuras institucionales de las Fuerzas Armadas.

Las declaraciones producidas en el transcurso de 1983 fueron, sin embargo, todavía más allá, aportando por primera vez referencias concretas a las identidades de los represores, algo que sólo había sucedido en las declaraciones producidas en el exilio. El día 22 de marzo ofreció su declaración en la causa otro de los sobrevivientes con pasado militante en VC que había atravesado el proceso de legalización junto a Watts y Machado. Con cuarenta y siete años, Faustino Fernández era el mayor del contingente de liberados. Había sido secuestrado de su casa ubicada en la localidad de Ciudadela, en el oeste de la Provincia de Buenos Aires, por un grupo identificado como parte de las "fuerzas conjuntas". Luego de pasar un mes en El Vesubio, fue legalizado y finalmente obtuvo su libertad definitiva del penal de La Plata en mayo de 1979.

Su declaración constituía una ampliación de otra efectuada casi cuatro años antes ante el juez Oliveri. Allí, Fernández afirmaba que:

momentos antes de ascender al camión, el deponente fue entrevistado por "el Francés", un oficial - no sabe si del Ejército o de la Policía- de 45 a 50 años de edad, delgado y con bigotes, de cabello negro y lacio, con un porte y rasgos similares de los del ex presidente Jorge Videla ${ }^{70}$.

La referencia a la identidad del personal de El Vesubio - en este caso, a la de uno de sus máximos responsables- significaba una novedad absoluta para los testimonios efectuados en el país. El clima de persecución existente y la inexistencia de un horizonte de justicia cercano habían funcionado seguramente como inhibidores a la hora de señalar a los responsables de la masacre dictatorial. En el nuevo contexto de 1983, eso parecía comenzar a cambiar. Atrás quedaban las declaraciones ante el juez Rivarola, en las que los sobrevivientes debían probar a toda costa su inocencia: en el ocaso dictatorial, los antiguos imputados pasaban a convertirse en testigos mientras los acusadores de antaño, poco a poco, calzaban el traje de acusados ${ }^{71}$.

\section{El Vesubio sale a la luz}

El 6 de diciembre de 1983, en la antesala de la asunción a la presidencia de Raúl Alfonsín, llegó al despacho del Dr. Oliveri un escrito con la firma de cinco personas que aseguraban haber dado con el sitio donde había transcurrido su secuestro ${ }^{72}$ :

\footnotetext{
${ }^{70}$ Juzgado Nacional de Instrucción en lo Criminal n³, op. cit., fs.223/ vta.

71 De ninguna manera se trató de una metamorfosis definitiva, como lo prueba el decreto presidencial nº157/83, que establecía la persecución penal de los líderes de las organizaciones político-militares.

72 Raúl Alfonsín (1927-2009), integrante de la Unión Cívica Radical (UCR), fue el primer presidente electo
} 
Los abajo firmantes nos hemos constituido en las inmediaciones de Camino de Cintura y Autopista Riccieri (sic), Partido de La Matanza, Provincia de Buenos Aires, y hemos accedido al predio en que se hallaba el centro clandestino de detención y tortura adonde fuimos llevados entre julio y agosto de $1978^{73}$.

Los nombres de los firmantes no eran extraños para el juez: entre ellos se contaban algunos de los sobrevivientes que habían declarado en la causa. El escrito, en el que los denunciantes se ponían a disposición del juez "para acompañarlo al lugar, a fin de darle su ubicación exacta" evidenciaba el trabajo realizado por su propia cuenta por los sobrevivientes: ese "atar cabos" al que se hacía referencia en una de las declaraciones anteriores. Una labor que por informal no había resultado menos efectiva que la del juez, sino todo lo contrario, ya que incluso había adelantado a los avances realizados por el funcionario judicial.

Al día siguiente de recibida la nota, como respuesta a la misma, el Dr. Oliveri ordenó una inspección urgente "en el predio señalado por los firmantes", "a efectos de conjurar todo riesgo de desaparición o alteración de pruebas materiales de los hechos investigados en autos"74. Esa misma tarde, una comitiva compuesta por el juez, su secretario y cuatro de los firmantes del documento se hizo presente en el lugar:

se aprecia gran cantidad de escombros, restos de mampostería, baldosas y ladrillos. Parcialmente, esas superficies de material se encuentran embaldosadas, con mosaicos de color rojizo y bordes blancos. Se divisa en uno de los sectores extremos de la superficie de material la base de un "water-closed" (sic) (...). También obran trozos de azulejos, rastros de mampostería con caños empotrados, bloques de material de diverso tamaño y demás restos de construcción ${ }^{75}$.

Los restos materiales apuntaban a la existencia de una edificación pretérita en el predio inspeccionado, la cual a todas luces había sido reducida a sus cimientos. Sin embargo, no se desprendía de ello que allí hubiera funcionado un CCD. No era ésta una constatación que pudiera establecerse puramente a partir del registro material obtenido, sino que se requería del apoyo de otro tipo de evidencia que permitiera dar el salto probatorio.

Esta brecha sería llenada por los testimonios de los sobrevivientes. Sin embargo, en el acta se dejaba constancia también de "la regular cantidad de árboles existentes en las cercanías a la zona, con hileras de eucaliptus, entre otras especies forestales", así como de "la frecuencia de vuelos de aviones" y del hecho de que desde el lugar era "posible divisar el ferrocarril que atraviesa la zona, a un kilómetro de distancia, aproximadamente" ${ }^{\text {76. Todas }}$ estas referencias habían aparecido en las declaraciones de los sobrevivientes que figuraban en el expediente de la causa que, de este modo, reforzaban la hipótesis de que se trataba de

democráticamente luego de más de siete años de dictadura en Argentina. Su asunción, que marcó el final del régimen militar, se produjo el 10 de diciembre de 1983.

${ }^{73}$ Juzgado Nacional de Instrucción en lo Criminal n³, op. cit., fs.283.

${ }^{74}$ Juzgado Nacional de Instrucción en lo Criminal n³, op. cit., fs.283-284.

75 Juzgado Nacional de Instrucción en lo Criminal n³, op. cit., fs.285.

76 Juzgado Nacional de Instrucción en lo Criminal n³, op. cit., fs.286. 
los restos materiales del CCD.

El procedimiento judicial se completó fuera del predio examinado, con la visita a un local de comidas aledaño:

Constituído el Tribunal en la parrilla "Pulpería La Gleba", contigua al lote inspeccionado, su titular (...) refiere a la instrucción que (...) en el lote colindante objeto de visita judicial- existía "un chalet de la Penitenciaría". Que el mismo fue demolido por personal con uniforme de fajina, llegado al lugar en camiones oficiales. Que esa demolición se concretó en un lapso que no puede precisar, aunque afirma que ha ocurrido "de cuatro años a esta parte"

Los vecinos de los lugares de reclusión ilegal jugaron un papel importante en el curso de la investigación de los crímenes dictatoriales durante la posdictadura argentina. En este caso, el testimonio se anticipaba en unos días al final del régimen militar, pero cumplía la misma misión: se trataba de un "tercero" extraño a los hechos indagados que corroboraba los dichos de los sobrevivientes, tanto en lo atinente a la pertenencia institucional del predio como en relación con las circunstancias y el momento de su demolición.

Mientras se realizaba la inspección ocular, el grupo de VC organizó una conferencia de prensa para difundir su presentación ante Oliveri, evento que tuvo lugar ese mismo 7 de diciembre. De la conferencia participaron Luis Zamora, abogado del CELS que representaba a los sobrevivientes y familiares de El Vesubio y reciente candidato en las elecciones presidenciales de octubre por el Movimiento Al Socialismo (MAS); Raúl Rabanaque Caballero, diputado electo por el Partido Intransigente (PI); y Mario Geller, Secretario Político del flamante Partido de la Liberación (PL) -nueva denominación de VC-. El evento recibió una amplia cobertura mediática de parte de periódicos nacionales y locales, que dedicaron espacio a la noticia de la identificación de un supuesto lugar de detención ilegal en un tramo del camino al aeropuerto internacional de Ezeiza. Luego de cinco años de investigación y de esfuerzo de denuncia sostenido, El Vesubio finalmente salía a la luz ${ }^{78}$.

\section{Conclusiones}

El retorno de la democracia, consumado el 10 de diciembre de 1983, abrió las puertas a una transformación del escenario político argentino a la que los sobrevivientes de El Vesubio no permanecieron ajenos: durante los primeros meses de 1984 se produjo la difusión mediática del hallazgo de fosas comunes y de la identificación de diversos CCD, acompañada por la reproducción de testimonios sobre la represión en dichos lugares, fenómeno bautizado por los propios contemporáneos como "el show del horror". En paralelo a esto, el nuevo gobierno llevó adelante una serie de medidas para investigar y procesar judicialmente los crímenes del período dictatorial, iniciativa que tuvo en la publicación del informe Nunca más de la CONADEP y en el Juicio a las Juntas sus

\footnotetext{
${ }^{77}$ Ibidem.

${ }^{78}$ En su edición del día 10 de diciembre, los periódicos Clarín, La Razón, Crónica y La Gaceta hicieron referencia a la denuncia efectuada por la localización de un supuesto lugar de detención clandestina.
} 
consecuencias más resonantes.

El éxito de la empresa por conocer, difundir públicamente y sancionar los crímenes del pasado inmediato, sin embargo, se apoyó sobre todo un trabajo de indagación y denuncia previos, que se remontaba a la etapa dictatorial. Sin el aporte del conocimiento acumulado durante esos años sobre el dispositivo represivo por parte del movimiento de derechos humanos, el Nunca más y el Juicio a las Juntas habrían visto enormemente disminuido su acervo documental y, con él, sus posibilidades de probar la existencia de la masacre efectuada. El caso de los sobrevivientes de VC, aun con las particularidades que lo rodean, es ilustrativo de dicho fenómeno.

Iniciado de manera aislada y casi fortuita, el esfuerzo por sacar a la luz los crímenes de la dictadura logró consolidarse gracias a la configuración de un colectivo de denuncia en el que los sobrevivientes desempeñaron el rol protagónico, pero para cuya consolidación fue fundamental también la participación de los familiares de sus compañeros de militancia desaparecidos y el apoyo de lo que quedaba en pie de las estructuras partidarias. Éstas últimas funcionaron a la vez como polo aglutinador y como herramienta de articulación con otros actores del movimiento de derechos humanos local. Ello supuso correr el eje de las prioridades del partido de la lucha revolucionaria a la denuncia en clave humanitaria, iniciativa de la que los sobrevivientes de VC participaron activamente.

Si para reconstruir la historia de la lucha contra la dictadura en Argentina es imprescindible recuperar las acciones desarrolladas por el movimiento de derechos humanos local, resulta igual de ineludible para la historia de este último examinar el rol desempeñado por los sobrevivientes de los CCD, tal como lo evidencia el caso aquí analizado. Tradicionalmente circunscriptos al papel de productores de relatos sobre los horrores de la represión clandestina, los sobrevivientes fueron en realidad mucho más que testigos, contribuyendo con un amplio repertorio de acciones al conocimiento y la denuncia de los crímenes dictatoriales.

\section{Bibliografía}

-Álvaro Abós, Las organizaciones sindicales y el poder militar (1976-1983), Buenos Aires: CEAL, 1984.

-Gabriela Águila et al, Represión estatal y violencia paraestatal en la historia reciente argentina. Nuevos abordajes a 40 años del golpe de Estado, Buenos Aires: FaHCE-UNLP, 2016.

-Luciano Alonso, "La definición de las ofensas en el movimiento por los derechos humanos en Argentina y la calificación de 'Genocidio"', en Contenciosa, Buenos Aires, Año I, No 1, 2013.

-Paula Canelo, El proceso en su laberinto. La interna militar de interna a Bignone, Buenos Aires, Prometeo, 2008.

-Lucía Castro Feijóo y Sofía Lanzilotta, Justicia y Dictadura. Operadores del plan cívico-militar en Argentina, Buenos Aires, Ediciones del CCC, 2014.

-Confino, Hernán. "Volver sin haberse ido: el caso de las 'Tropas de Agitación Sur' durante la Contraofensiva Estratégica Montonera de 1979', en Revista Universitaria de Historia Militar (en prensa).

-Débora D'Antonio, Transformaciones y experiencias carcelarias. Prisión política y sistema penitenciario en la Argentina entre 1974 y 1983, Tesis de Doctorado en Historia, Buenos Aires, 
Facultad de Filosofía y Letras, UBA, 2010.

-Christian Dürr, Memorias incómodas. El dispositivo de la desaparición y el testimonio de los sobrevivientes de los Centros Clandestinos de Detención, Tortura y Exterminio, Temperley, Tren en Movimiento, 2017.

-Claudia Feld y Luciana Messina, "En torno a la palabra testimonial de los sobrevivientes: testigos legitimados y denegados de los centros clandestinos de detención en Argentina", en Tramas, n41, 2014.

-Ana Forcinito, Los umbrales del testimonio. Entre las narraciones de los sobrevivientes y las señas de la posdictadura, Madrid, Iberoamericana, 2012

-Marina Franco, El exilio. Argentinos en Francia durante la dictadura, Buenos Aires, Siglo XXI, 2008.

-Marina Franco, Un enemigo para la Nación. Orden interno, violencia y subversión, 1973-1976, Buenos Aires, Fondo de Cultura Económica, 2012.

-Marina Franco, "Los derechos humanos en los años 80 dictatoriales: un viejo problema bajo nuevas preguntas", ponencia presentada en las VII Jornadas de Trabajo sobre Historia Reciente, Rosario, Facultad de Humanidades, 2016.

-Richard Gillespie, Soldados de Perón. Historia crítica sobre los Montoneros, Buenos Aires: Sudamericana, 2008.

-Carlo Ginzburg, "Microhistoria: dos o tres cosas que sé de ella", en El hilo y las huellas. Lo verdadero, lo falso, lo ficticio, Buenos Aires, FCE, 2014.

-Rodrigo González Tizón, "'Cada voz que se alce puede salvar una vida en Argentina'. La producción testimonial de los sobrevivientes de los Centros Clandestinos de Detención en el marco de la Comisión Argentina por los Derechos Humanos (1979-1983), en Papeles de Trabajo, 10(17), 2016.

-Elizabeth Jelin, "La política de la memoria: el movimiento de derechos humanos y la construcción democrática en la Argentina", en Juicio, castigo y memorias. Derechos humanos y justicia en la política argentina, Buenos Aires, Nueva Visión, 1995.

-Silvina Jensen, Los exiliados. La lucha por los derechos humanos durante la dictadura, Buenos Aires, Sudamericana, 2010.

-Silvina Jensen, "Los exiliados argentinos y las luchas por la justicia (1976-1981)", en Estudios, n⿳30, julio-diciembre 2017.

-Vania Markarian, Idos y recién llegados. La izquierda uruguaya en el exilio y las redes transnacionales de derechos humanos, 1967-1984, Montevideo: Correo del Maestro, 2006.

-Marcos Novaro y Vicente Palermo, La dictadura militar 1976-1983: del golpe de Estado a la restauración democrática, Buenos Aires, Paidós, 2006.

-Brenda Rupar, A emergência do Maoismo na Argentina: uma aproximaçao através de Vanguardia Comunista $e$ o Partido Comunista Revolucionario, Tesis de maestría en Historia, Universidad de Fluminense, 2016.

-María José Sarrabayrouse Oliveira, Etnografía de las prácticas y procedimientos en la justicia penal durante la dictadura militar (1976-1983), Tesis de Doctorado con mención en Antropología, Buenos Aires: Facultad de Filosofía y Letras, UBA, 2008.

-Ana Carol Solís, "De las comisiones a los organismos en Córdoba: derechos humanos, dictadura y democratización”, en Rubén Isidoro Kotler (comp.), En el país del sí me acuerdo. Los orígenes nacionales e internacionales del movimiento de derechos humanos argentino: de la dictadura a la transición, Buenos Aires, Imago Mundi, 2014.

-Américo Soto, Vidas y luchas de Vanguardia Comunista, Buenos Aires, Ediciones Nuevos Tiempos, 2004.

-Nadia Tahir, Les asociations des victimes de la dictature: politiques de droits de l'homme et 
devoir de mémoire en Argentine (1976-2007), Tesis de doctorado, Université Paris-Sorbonne, 2011.

-Mariana Tello, "Yo acuso: un análisis antropológico sobre lo jurídico en los primeros testimonios sobre 'La Perla"', en Clepsidra, Revista interdisciplinaria de estudios sobre memoria $\mathrm{n}^{\circ} 4,2015$.

-Pablo Yankelevich, Ráfagas de un exilio. Argentinos en México: 1974-1983, Buenos Aires, Fondo de Cultura Económica, 2010.

\section{Fuentes escritas}

-Centro de Estudios Legales y Sociales, "Informe sobre la situación de los derechos humanos en Argentina", 1980.

-Centro de Estudios Legales y Sociales, "Un caso judicial revelador", 1982.

-Centro de Etudios Legales y Sociales, "La doctrina del paralelismo global", 1981

-Honorable Congreso de la Nación, "Ley 20.840/ 78"

-Juzgado Nacional de Instrucción en lo Criminal no 3 , causa $n^{\circ} 35.040 / 78$, “Ávalos de Guarido, Isabel s/denuncia", fs. 1-2.

\section{Entrevistas}

-Paulino Guarido, entrevista con el autor, Ciudad Autónoma de Buenos Aires, 24 de septiembre de 2015.

-Guillermo Lorusso, entrevista con el autor, Ciudad Autónoma de Buenos Aires, 13 de julio de 2015.

-Jorge Watts, entrevista con el autor, Ciudad Autónoma de Buenos Aires, 21 de noviembre de 2014. 